\title{
部分安定化ジルコニア薄板ばねの強度特性についで
}

\author{
佐藤繁美**，安達隆介**，東野豊之**，小山 博**
}

\section{Strength and Fatigue Properties of Thin Leaf Spring Made of Partially Stabilized Zirconia}

\author{
Shigemi Sato, Ryusuke Adachi, Toyoyuki Higashino \\ and Hiroshi Koyama
}

\begin{abstract}
Synopsis
Strength and fatigue life of a thin leaf spring, which was made of PSZ and was fabricated by hot-pressing, were observed to estimate the possibility of ceramics as a spring material.

Four-point bending test, cyclic bending fatigue test at room temperature and static fatigue test at $573 \mathrm{~K}$ were carried out for the estimation of the strength. From the results of the above test, it is found that the PSZ has rather low heat resistivity and the strength of the material scattered widely. Therefore the greatest care on the effect of the temperature and the scattering of the strength are required to design a PSZ spring. The fatigue life, which is important to design a spring, can be estimated by using the crack propagation rate and Weibull distribution function.
\end{abstract}

\section{1. 緒言}

セラミックスは金属に比べて耐熱性，耐食性， 耐摩耗性にすぐれており，とくに高温材料として 脚光を谷びているるのである。セラミックスの欠 点は脆性な点にあるが，近年のセラミックス製造 技術の進歩に伴いかなり改善され，窒化ヶイ素， 炭化ケイ素，サイフロン，部分安定化シルコニア (Partially Stabilized Zirconia，以下 PSZ と略 称などが高強度セラミックス材料として注目さ れるようになってきた。

昭和61年 8 月 9 日 受付

*ばね技術研究会 昭和61年春季講演会にて発表 **掝日発グループ中央研究所
とくに, PSZ は室温近傍の低温域で準安定な正 方晶に応力が作用すると，き裂先端近傍の応力場 で正方晶粒子が応力誘起マルテンサイト変態によ り安定な単斜晶になり，き裂伀播のためのエネル ギーの一部を変態過程で吸収することから強勒化 する”。また，研削によっても表面近傍の正方晶が 単斜晶に变態し，変態による体積膨張により表面 に王縮残留応力層が形成され強度が向上すること が知られている21,3)。

本稿では，ばね材料としてのセラミックスの可 能性を探ることを目的として行った PSZ 薄板ば ねの強度特性評価，およびばね設計上重要な疲労 寿命予測の試みについて報告する。 


\section{2. 実 験 方 法}

\section{1 供試材および試験片}

東洋曹達工業製 $3 \mathrm{~mol}^{-} \mathrm{Y}_{2} \mathrm{O}_{3}$ の PSZ粉末を用 い，Fig. 1 に示す工程により各種試験片を作成し た。PSZ 粉末の焼結はホットプレスで真空中, 温 度 $1723 \mathrm{~K}$, 保持時間 $1 \mathrm{~h}$, 加圧 $29.4 \mathrm{MP}_{\mathrm{a}}$ の条件で行 った。焼結体は平均粒径 $0.3 \sim 0.4 \mu \mathrm{m}$ (Photo. 1 ), 比重6.08，破壊靯性值 $7 \mathrm{MN} / \mathrm{mm}^{3 / 2}$ であった。

試験片は焼結体をダイヤモンドカッタで所定の 幅に切断後表面仕上げして得た。試験片寸法は曲 げ試験が $3 \times 4 \times 40 \mathrm{~mm}$ ，疲労試験が $0.8 \times 7 \times$ $75 \mathrm{~mm}$ である。表面仕上げは加工による残留応力 の強度への影響を調べるために平面研削とバフ研 磨の 2 条件とした。平面研削仕上げの場合，\#200

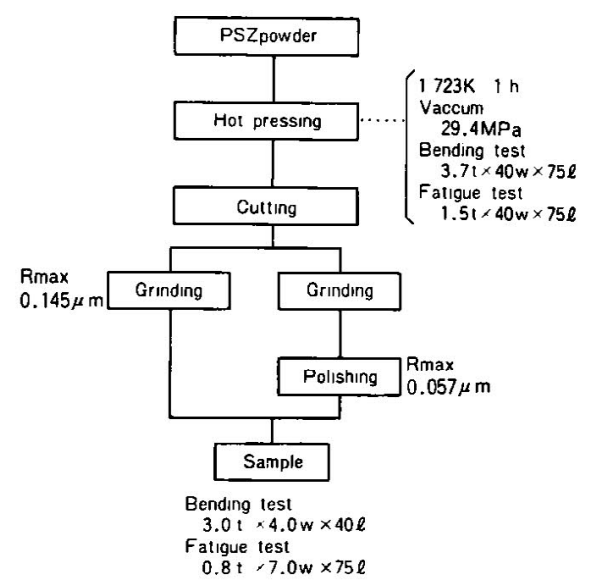

Fig. 1. Flow diagram of manufacturing process.

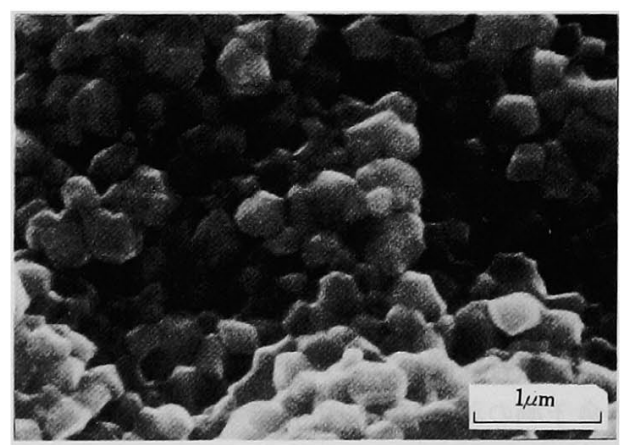

Photo. 1. Crystal grain size at the fracture surface of PSZ.

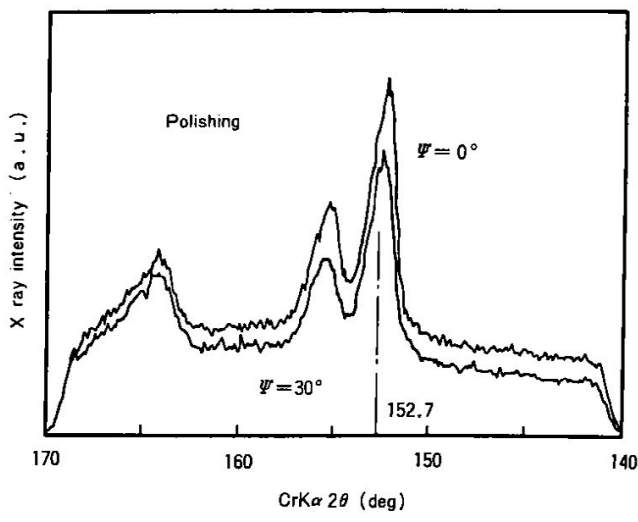

Fig. 2. $\mathrm{X}$ ray intensity vs. $2 \theta$ (Residual stress was observed from the shift of the peak position).

のダイヤモンドホイールを用い，バフ研磨仕上げ の場合，同じ砥石で研削後，研削による変態㕌を 除去するために $6 \mu \mathrm{m}$ のダイヤモンド䂼粒を用い 両面を $50 \mu \mathrm{m}$ 研磨した。打のおのの表面仕上げ後 の表面粗さ $\mathrm{R}_{\text {max }}$ は平面研削の場合 $0.415 \mu \mathrm{m}$ ， ハ

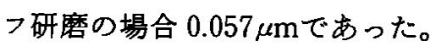

2.2 単斜晶量の測定と残留応力測定 試験片表面の単斜晶量の測定にはX 線回折装置 を用い(1)式によって算出した4)。

$$
\text { 単斜晶量 }(\%)=\frac{I_{m}(111)+I_{m}(11 \overline{1})}{I_{m}(111)+I_{m}(11 \overline{1})+I_{t}(111)}
$$

ここで, $I_{m}(111), I_{m}(11 \overline{1})$ は単斜晶の(111), お よび(11̄i)の積分強度, $I_{t}(111)$ は正方晶の(111)の 積分強度である。

また, 残留応力の測定にはX線応力測定装置を 用いて，(2)式の $\sin ^{2} \psi$ 法で算出した。

$$
\begin{aligned}
& \sigma=-\frac{E}{2(1+\nu)} \cdot \cot \theta_{0} \cdot \frac{\pi}{180} \cdot \frac{\partial(2 \theta)}{\partial\left(\sin ^{2} \psi\right)} \\
& K=-\frac{E}{2(1+\nu)} \cdot \cot \theta_{0} \cdot \frac{\pi}{180} \\
& =-305(\mathrm{MPa} / \mathrm{deg}) \ldots \ldots \ldots \ldots \ldots \ldots \ldots \ldots \ldots \ldots \ldots \ldots \ldots
\end{aligned}
$$

ここで, 縦弾性係数を $196 \mathrm{GP}_{\mathrm{a}}$, ポフンン比を 0.28 とし, 回折線はFig. 2 に示すよ5に $d=$ $1.178 \AA\left(\mathrm{C}_{\mathrm{r}} \mathrm{K}_{\alpha}\right.$ で $\left.2 \theta_{0}=152.7^{\circ}\right)$ を用いた。

\section{3 強 度 試 験}

強度試験として，4 点曲げ試験, 静的疲労試験, 繰返し疲労試験を行った。おのおの試験装置の概 

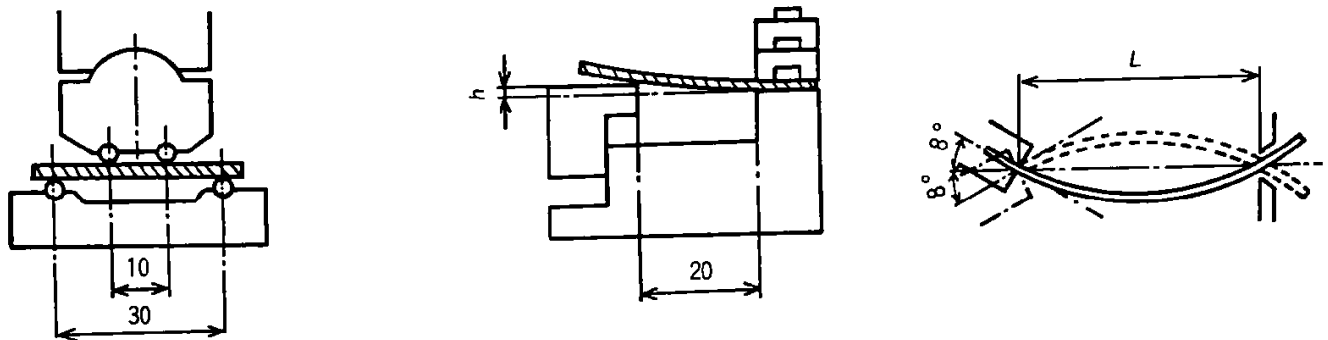

Fig. 3. Schematic illustration for bending and fatigue test.

要を Fig. 3 に示すとともに，試験方法を以下にま とめた。

\subsubsection{4 点曲げ試験}

室温から $1473 \mathrm{~K}$ ず大気中で 4 点曲げにより 曲げ強度を求めた。試験方法は JIS R 1601 に準し て行い,クロスーッド速度は $0.5 \mathrm{~mm} / \mathrm{min}$, 各温度 に昇温後の保持時間は $15 \mathrm{~min}$ とした。

\subsection{2 静的疲労語験}

PSZは473 573Kの低温域に長時間保持され ると，この温度域で準安定な正方晶が安定な単斜 晶に変態し，き裂が生じ強度低下することが知ら れている5゙。そこで，573Kの温度で静的疲労試験

（締付け試験）を行い，変態促進に寄与すると考 えられる負荷応力と破罗までの時間との関係を求 めた。負荷方法は片持ちはり方式でスパンは $20 \mathrm{~mm}$ とした。

\subsection{3 繰返 L疲労試験}

室温における両振り曲げ繰返し疲労試験には港 精機研究所製薄板ば称疲労試験機を用いた。応力 は $\sigma=3 \cdot t \cdot E \sin \theta / 2 L(t$ : 板厚, $\theta$ : 回転角, $L$ : スパン， $E$ : 緥弾珄係数）より算出し，最大応力 部近傍に歪ゲージを数枚貼付し応力梌定も行っ た。Eを196GP よって応力設定をした。また，繰返し速度は $716 \mathrm{cpm}$ 一定で, $10^{7}$ 回打切りの試験である。

\section{3. 実験結果および考察}

\section{1 単斜晶量と表面残留応力}

Fig. 4kX線回折プロフィルを, Table 1 に単 斜晶量と表面残留応力の測定結果を示す。平面研 削では表面層に単斜晶が2.49\%認められ，正方晶 から単斜晶への変態に伴う体積膨張により表面の

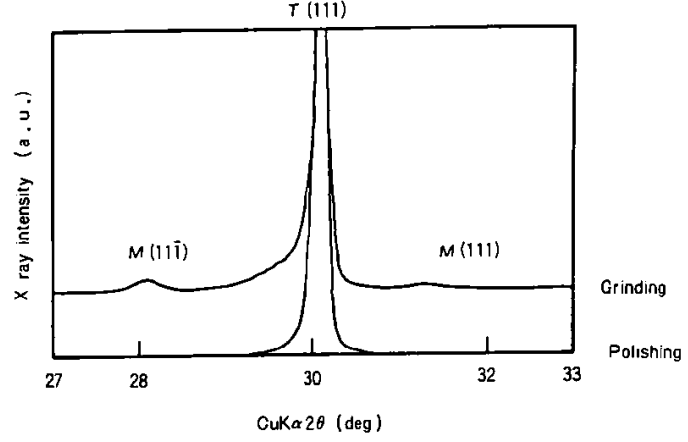

Fig. 4. Effect of surface finishing on $\mathrm{X}$ ray diffraction profile.

Table 1. Monoclinic content and residual stress.

\begin{tabular}{|c|c|c|c|}
\hline \multicolumn{2}{|c|}{ Surface finishing } & Grinding & Polishing \\
\hline \multicolumn{2}{|c|}{ Monoclinic content $(\%)$} & 2.49 & 0.23 \\
\hline \multirow{2}{*}{$\begin{array}{l}\text { Residual } \\
\text { stress } \\
\text { (MPa) }\end{array}$} & $\begin{array}{l}\text { Longitudinal } \\
\text { direction }\end{array}$ & $\begin{array}{l}-195 \\
-246\end{array}$ & 13 \\
\hline & $\begin{array}{l}\text { Transverse } \\
\text { direction }\end{array}$ & $\begin{array}{l}-593 \\
-317 \\
-399\end{array}$ & -2 \\
\hline
\end{tabular}

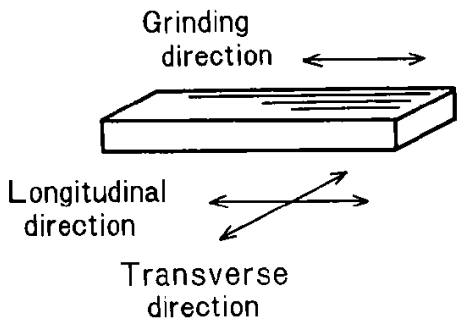


王縮残留応力が $200 〜 600 \mathrm{MP}$ 、になった。とくに， 研削方向に直角な板幅方向で残留応力が大きい。 一方，研削後 $50 \mu \mathrm{m}$ バフ研磨することにより变態 層が除去され，表面残留応力す注ぼぜ口となった。

\section{2 強 度 試 験}

\section{2 .14 点曲げ試験}

4 点曲げ試験結果を Fig. 5 に示す。室温近傍で は高強度であるが，温度上昇に伴い急激に強度が 低下し，1173K 以上で約 200MPa これは，室温近傍では变態によって高強度化され るが，高温では正方晶が安定化し変態が扣こりに くくなり強化されないためである。また，1473K では塑性変形したため, 破断までの試験が不可能 であった。

さらに, 平面研削とバフ研磨の強度を比較して みると， $873 \mathrm{~K}$ までは平面研削の強度がバフ研磨

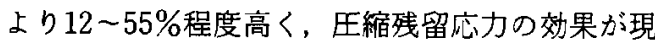
われているものと考えられる。しかし，1073K以 上では両者とも同程度の強度となった。これは， 正方晶の安定化と残留応力の减少によるものと考 えられる。

\subsection{2 静的疲労試験}

$573 \mathrm{~K} て ゙$ 片持ち曲げの静的疲労試験を行うた結 果をFig. 6 に示す。500MPa 以上の応力ではバ 研磨の 2 試験片を除き， $10^{6} \mathrm{sec}$ をでに破壊し，負 荷応力が高いほど短寿命となった。これは, PSZ では金属ばねの上らなへたりは示さず，準安定な 正方晶が安定な単斜晶へ変態し, 变態に伴う膨張 に上りき裂が生じて破壊したものと考えられる。

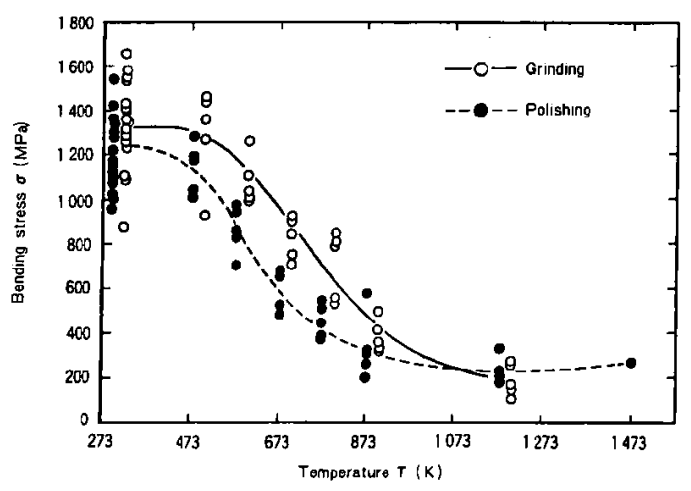

Fig. 5. Four-point bending strength of PSZ at high temperature.
平面研削とバフ研磨の静的疲労寿命を比較する ために両者の平均的な疲労寿命を求めた。すなわ ち，七ラミックスの上らな脆性材料において，き 裂伝播速度と応力拡大係数から応力 $\sigma$ と破壊まで の時間 $t r$ と間には(3)式が成立する7)。

$$
\sigma^{N} \cdot t_{s}=\mathrm{const}
$$

ここに,Nはセラミックス拉よび試験雾囲気で 定める定数。

そこで（3)式の定数を平面研削とバフ研磨につ いてそれぞれ最小自乗法により求めると以下のよ らになりこれらの関係式を Fig. 6 に曲線で示し た。

$$
\begin{array}{ll}
\text { 平面研削 } & \sigma^{8.87} \cdot t_{f}=1.27 \times 10^{29} \\
\text { バフ研磨 } & \sigma^{16.16} \cdot t_{f}=2.63 \times 10^{49}
\end{array}
$$

両曲線は応力 $\sigma 612 \mathrm{MP}_{\mathrm{a}}$, 破壊までの時間 $t_{s}$ $2.38 \times 10^{4} \mathrm{sec}($ 約 $6.6 \mathrm{~h})$ で交差し， $t_{\mathrm{s}}$ は612MP $\mathrm{M}$ 以上 の高応力側では平面研削が，また低応力側ではバ フ研磨が長くなった。この原因は, 短時間で破壊 する高応力では圧縮线留応力の効果が疲労強度に 大きく寄与したためであり，圧縮残留応力の大き い平面研削の寿命が長くなったものと考竞られ る。一方, 長時間で破壊する低応力では变龍に伴 う劣化のほうが疲労強度に奇与したためであり， すでに加工により表面睥が变態している平面研削 の寿命が短くなったものと考えられる。このこと から、ばねとして低応力で長時間使用する場合は 平面研削を施さない娃らがよいと思われる。

従来から知られているよらに正方晶が安定化す る高温での強度低下 (Fig. 5) と 473～573K の温度

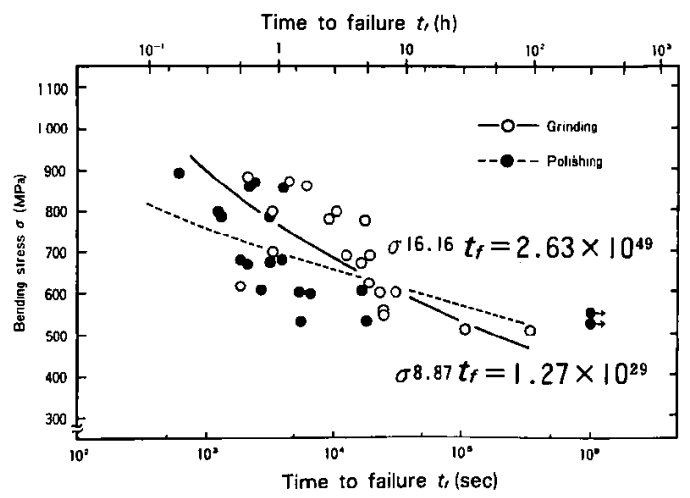

Fig. 6. Static fatigue data for PSZ at $573 \mathrm{~K}$. 
域における脆性を考え合わせると，PSZをばねと して使用できる温度は室温に限定されるむのと考 えられる。

\section{2 .3 繰返し疲労誈験}

室温で両振り曲げ絽返し疲労試験を行った結果 を Fig. 7 に示す。試験応力範囲に疲労限は認めら れず，金属に比べて非常にばらつきが大きい。

ここで, 平面研削とバフ研磨の疲労寿命を比較 するために両者の平均的な疲労寿命を求めた。す なわち,この絽返し㝿労試験では絽返し速度を一 定にして行っているので(3)式と同様に(4)式が導き 出せる。

$$
\sigma^{N} \cdot n_{f}=\text { const }
$$

静的疲労試験の場合と同様に(4)式の定数を平面 研削とバフ研磨についてそれぞれ最小自乗法によ り求めると以下のようになり, これらの関係式を Fig. 7 に曲線で示した。

平面研削 $\sigma^{4.0} \times n_{f}=10^{127.8}$

バフ研䧹 $\sigma^{44.0} \times n_{f}=10^{126.2}$

両曲線はほぼ平行であり, 平面研削はバフ研磨 に比べ, 同一応力に招いて繰返し数が10倍で寿命 が長い。これは, 圧縮残留応力の効果が疲労強度 に大きく寄与したためで，室温，106 $\mathrm{sec}(227.8 \mathrm{~h})$ の繰返し応力を受けた程度では変態に伴う劣化は ないと考えられる。

なお，セラミックスの疲労強度は応力負荷速度 の影響を受けやすく，応力負荷速度を遅くすると 強度は低下する ${ }^{81,99}$ 。さらに, PSZ は变熊が関与す るため, 応力負荷速度を遅くし, 長時間にわたる 繰返し疲労を受けた場合, 变態が疲労強度低下に どの程度影響するかる今後検討する必要がある。

\subsection{4 疲学寿命予測}

セラミックスの静的疲労寿命予測にはき裂伝播 速度と応力払大係数上り求をる前述の(3)式と SPT 線 図(Strength-Probability-Time diagram ${ }^{109}$ が多用されている。前者は平均的な疲労 寿命を表わするので, 寿命のばらつきまでは考虑 されていない。一方, 後者は前者と同様にき裂伝 播速度, 応力拡大倸数と，さらに寿命のばらつき を考虑したもので, ある一定応力に括ける疲労寿 命をもとにワイブル統計に従って破壊確率を求め るものである。そのため, 今回の疲労試験の上う な種々の応力で試験を行い $\mathrm{S}-\mathrm{N}$ 線図を求めよう としたデータには適用が困難である。そこで,こ

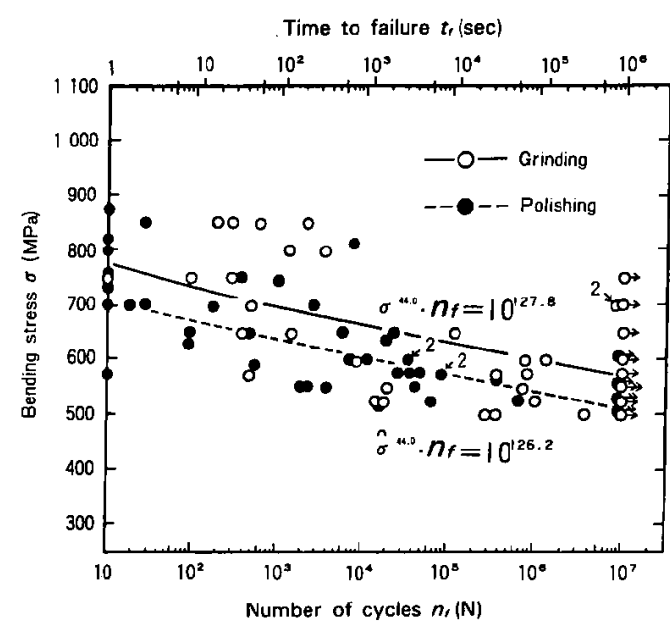

Fig. 7. Cyclic bending fatigue data for $\mathrm{PSZ}$ at room temperature.

こではこのょうな試験にも適用できるK.Jakus らが行った方法 ${ }^{8), 11), 12\}}$ を用いて疲労寿命予測の可 能性を検討した。以下にその方法を述べる。

Fig.6,7 の疲労試験結果から明らかな上らに, セラミックスの疲労強度は大きなばらつきを示し ている。これは, 強度がセラミックス中に存在す ろ欠宿の種類, 形状, 大きさに依存するためであ る。このことから，セラミックスの強度は統計的 な量として取扱われ ${ }^{13)}$ （5)式に示すワイブル分布 関係が用いられている。

$$
F=1-\exp \left\{-\left(S_{i} / S_{o}\right)^{m}\right\}
$$

ここに, Fは破壊確率, $S_{i}$ は不活性強度 (inert strength)，Soは規格化定数，mはワイブル係数で ある。

また, セラミックスのような脆性材料において， き裂の長さ $a$ ，その伝播速度を $v$ とすると，(6)式 が成立する(4)。

$$
v=\mathrm{d} a / \mathrm{d} t=A \cdot K_{I}^{N}
$$

ここに，A，Nはセラミックスおよび試験雾团 気で定まる定数, $K_{I}$ は応力拡大係数で応力 $\sigma_{a}$ と (7)式の関係にある。

$$
K_{I}=\sigma_{a} \cdot Y \sqrt{a}
$$

ここに，Yはセラミックスとき裂形状に依存す る係数である。

㐫力 $\sigma_{a}$ で破壊するまでの時間 $t_{f}$ は初期き裂 $a_{i}$ が成長し $a_{c}$ になるまでの時間, すなわち $K_{r i}(=$ $\left.\sigma_{a} Y \sqrt{a_{i}}\right)$ 加 $K_{l c}\left(=\sigma_{a} Y \sqrt{a_{c}}\right.$, 臨界応力抎大係数 $)$ 

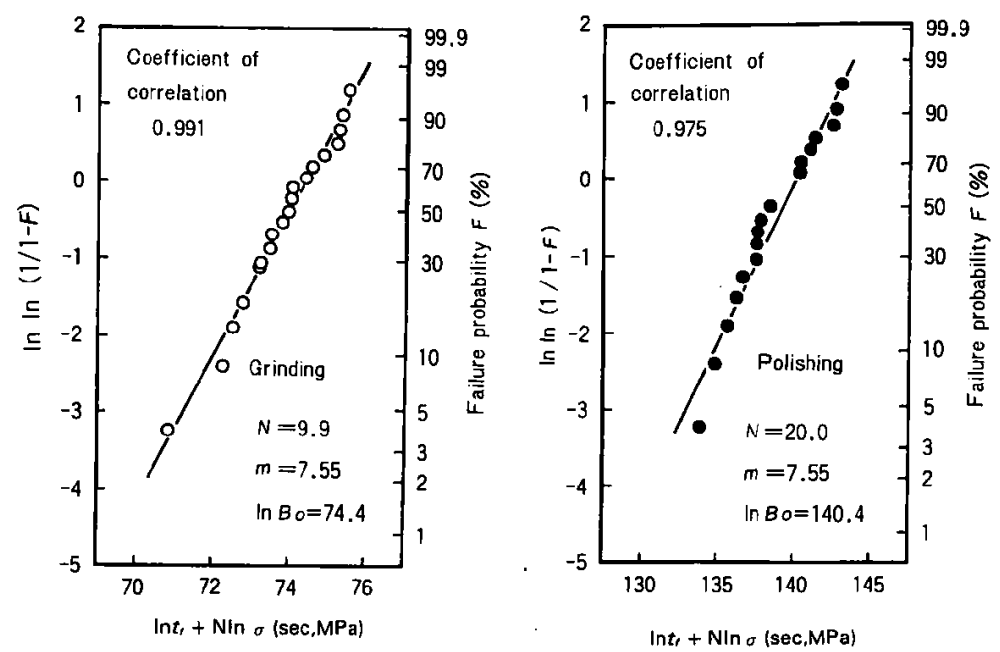

Fig. 8. Weibull plot of static fatigue data for PSZ at $573 \mathrm{~K}$.

になるまでの時間に等しいことから(8)式が得られ る。

$$
t_{f}=B \cdot S_{i}^{N-2} \cdot \sigma_{a}^{-N}
$$

ここに, $B=2 /\left\{A Y^{2}(N-2) K_{/ c}{ }^{N-2}\right\}$ である。 た（8)式は $K_{l \mathrm{c}}=S_{i} \cdot Y \sqrt{a_{i}}$ とし，Nは十分大きいと して得られたものである。

次に，(5)式の両辺を 2 度対数をとると(9)式とな $\eta$,

$$
\ln \ln (1 / 1-F)=m \ln \left(S_{i} / S_{0}\right)
$$

(8)式と(9)式より(10)式が得られる。

$$
\begin{gathered}
\ln t_{s}+N \ln \sigma_{a}=\ln B_{o}+\{(N-2) / m\} \ln \ln (1 / 1-F) \\
\ln B_{o}=\ln B+(N-2) \ln S_{o} \quad \cdots \ldots \ldots \ldots \ldots \ldots \ldots(10)
\end{gathered}
$$

$\ln t_{s}+N \ln \sigma_{a}$ と $\ln \ln (1 / 1-F)$ とは比例関係に あり, 定数 $B_{o}, m, N$ を求めれば任意の応力 $\sigma_{a}$, 時間 $t_{s}$ に対する破壊確率 $F$ が得られる。定数 $B_{o}$, $m$ は疲労試験によって得られたデータ $\ln t_{f}$ $+N \ln \sigma_{a} z \ln \ln (1 / 1-F)$ に対してプロットし,こ の傾きと切片より求める。しかし，Nは前もって 求めることができないため，最小自乘法により $\ln t_{f}+N \ln \sigma_{a}$ と $\ln \ln (1 / 1-F)$ との相関係数が最 も高くなるよらなNを繰返し計算によって求める 必要がある。

本実験の静的疲労試験データについて $N$ を変え $\tau \ln t_{s}+N \ln \sigma_{a}$ と $\ln \ln (1 / 1-F)$ との相関係数を 求めてみた。Fig. 8 は相関係数が最も高くなった ときのワイブルプロットである。このときの相関 係数は非常に高く，よい直線性が得られた。この

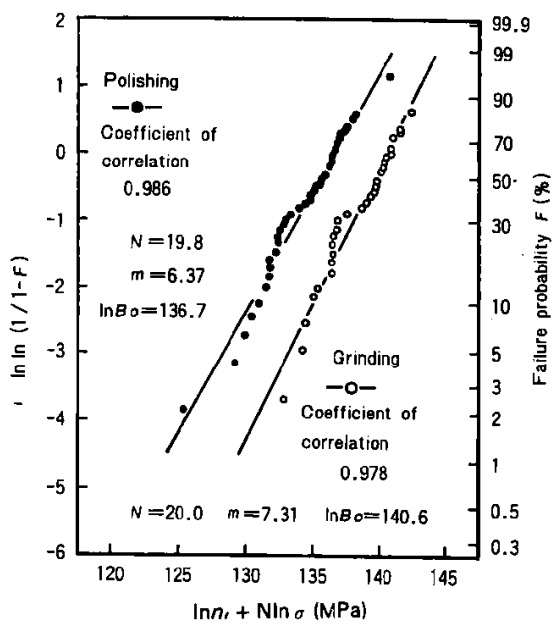

Fig. 9. Weibull plot of cyclic bending fatigue data for PSZ at room temperature.

ことから，(10)式を用いて静的疲労の寿命予測が可 能であると考えられる。

次に，繰返し疲労試験についてあ(10)式の適用を 試みた。本実験では繰返し速度を一定で行ってょ $\eta$ ，綝返乙数 $n_{f}$ と破壊までの時間 $t_{f}$ とは比例関 係にある。そこで, $(10)$ 式の $t_{f}$ を $n_{f}$ に置換えて本実 験の繰返し疲労試験データについて前述の静的疲 労試験と同様な検討を行った。結果を Fig.9 亿示 す。このときの相関係数も静的度労試験と同様非 
常に高く, 繰返し速度が一定な繰返し疲労試験の 寿命予測が可能であることがわかった。

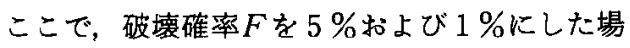
合の静的疲学試験扣よび繰返し疲労試験の寿命予 測を行った結果をそれぞれ Fig. 10，Fig. 11 に示 す。

Fig. 10 の静的疲労試験において，破壊確率 $F$ を $1 \%$ とし，破壊までの時間 $t_{f} か ゙ ~ 10^{5} \mathrm{sec}$ (約1.1day) の応力を求めると，平面研削で $353 \mathrm{MP}_{\mathrm{a}}$ ，バフ研磨 で356とほぼ同等である。さらに，t， $10^{7} \mathrm{sec}($ 約 115day）まで外とらすると平面研削が 222MPa, バフ研磨が $283 \mathrm{MP}_{\mathrm{a}}$ ，と曲げ強度の $1 / 4$ 程度まで低 下する。

次に, Fig.11 の繰返し疲労試験に扣いても破壊 確率 $F$ を $1 \%$ とし, 繰返乙数 $n_{f}$ が $10^{7}$ 回 $\left(t_{f}\right.$ 232.8h) に打ける応力を求めてみると, 平面研削が $287 \mathrm{MP}_{\mathrm{a}}$, バフ研磨が $231 \mathrm{MP}_{\mathrm{a}}$, とかなり低い值と なった。 $10^{7}$ 回で, 破壊確率Fが $1 \%$ の応力を疲労 限と想定して室温の曲げ強度との比を求めると 0.18〜0.21となり，金属ば权の0.25〜0.40(この 場合，疲労限/引張り強度）より低い。したがっ て、ばねのように動的な使われ方をする場合, PSZ の設計応力は非常に低くする必要がある。

\section{4. 結}

PSZの薄板ばねを用いて強度特性評価を行う とともにばね設計上重要な疲労寿命予測の試み を行い以下の知見を得た。

（1）PSZの強度特性には変態が大きな影響を およぼし，したがってばねとして使用する場合， 温度, 負荷応力, 時間などの要因を考慮する必要 がある。

（2）疲労寿命のばらつきが大きく，設計許容応 力はきわめて低くなる。

（3）破壊力学的手法とワイブル分布関数を用い た(10)式によれば疲労寿命は予測しうる。

今回, PSZ の材料強度的側面よりばねとしての 可能性の検討を加えたが，金属ばねとの相違を改 めて認識した次第である。すなわち，材料，製造

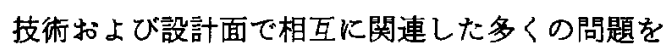
含んで扣り，これらが解決されて初めてばねとし て実用化されよう。

最後に本研究汇当り御指導, 御支援をいたたい た日本発条大野明顧問（当研究所前取締役社

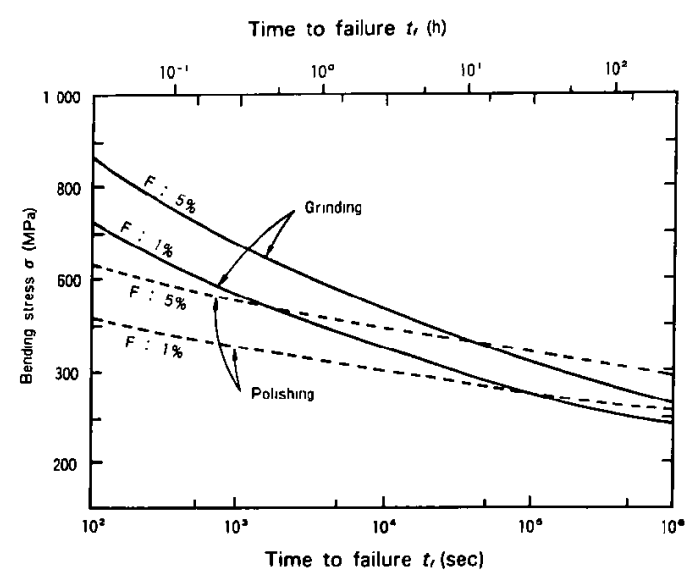

Fig. 10 Failure probability diagram for PSZ on static fatigue data at $573 \mathrm{~K}$.

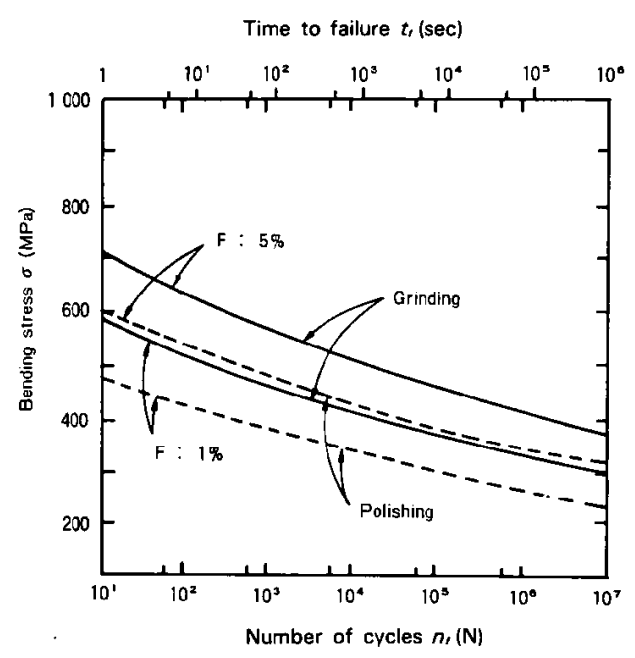

Fig. 11. Failure probability diagram for PSZ on cyclic bending fatigue data at room temperature.

長), 当研究所高津幸弘専務取締役に謝意を表しま す。

\section{(文献)}

1) A.G.Evans and A.H.Heuer: J.Am. Ceram. Soc., 63 (1980), 241

2) D.J.Green, F.F.Lange and M.R.James:J. Am. Ceram. Soc., 66 (1983), 623

3) T.K.Gupta: J.Am. Ceram. Soc., 63 (1980), 117 
4) R.C.Garvie and P.S.Nicholson : J.Am. Ceram. Soc., 55 (1972), 303

5 ）鳥井秀雄, 沖中秀彦, 宮沢陖彦, 满田宏通: 粉体优よび粉末治金，31（1984），177

6) 薄板ばね強度委員会：ばね技研春期講演会前 刷集，(1984)， 33

7) J.E.Ritter Jr.: Fracture Mechanics of Ceramics, Vol.4, edited by R.C.Bradt, D.P. H. Hasselman and F.F.Lange, (1978), 667 [Plenum Press, New York]

8) K.Jakus, D.C.Coyne and J.E.Ritter Jr:J. Mater. Sci., 13 (1978), 2071
9）芦塚正博，清原秀樹，石田英一，桑原 誠， 窪田吉孝, 月舘隆明：宰業協会誌, 94(1986), 432

10) R.W.Davidge, J.R.McLaren and G. Tappin: J.Mater. Sci., 8 (1973), 1699

11) K.Jakus and J.E.Ritter Jr:J.Am. Ceram. Soc., 61 (1978), 274

12）田中英彦：化学と工業，32（1979），200

13）松尾陽太郎：セラミックス, 20 (1985)，19

14) A.G.Evans: Fracture Mechanics of Ceramics, I(1976), 17[Plenum Press, New York] 